УДК 615.322:[581.144.4:633.878.32]].074 DOI: 10.32352/0367-3057.3.21.06
А. М. РУДНИК (https://orcid.org/0000-0003-2860-0967), канд. фарм. наук, доцент
Запорізький державний медичний університет
ДОСЛІДЖЕННЯ СПОЛУК, ЩО ПЕРЕГАНЯЮТЬСЯ 3 ВОДЯНОЮ ПАРОЮ,
ЛИСТЯ РОPULUS LAURIFOLIA LEDEB.

Ключові слова: Populus laurifolia Ledeb., вербові, листя, сполуки, що перегоняются 3 водяною парою, хромато-мас-спектрометрія

A. M. RUDNYK (https://orcid.org/0000-0003-2860-0967)

Zaporizhzhia State Medical University

\title{
THE STUDY OF COMPOUNDS DISTILLED WITH WATER VAPOR OF POPULUS \\ LAURIFOLIA LEDEB. LEAVES
}

Key words: Populus laurifolia Ledeb., willow family, leaves, compounds distilled with water vapor, gas chromatography-mass spectrometry

Одними з перспективних видів для внесення до Державної фармакопеї України є рослини роду Тополя (Populus L.). На сьогодні накопичено великий досвід застосування екстрактів із бруньок, листя та кори різних видів тополь у народній й офіціальній медицині як ефективних протизапальних, жарознижувальних, аналгетичних, антибактеріальних засобів [1].

За даними літератури, фармакопейною сировиною у деяких державах світу є тільки бруньки тополь. Наприклад, у Великій Британії фармакопейними видами є: тополя чорна (P. nigra L.), т. бальзамічна (P. balsamifera L.), т. великолиста (P. candicans (syn. P. gileadensis)) [2]; у Німеччині: т. чорна; у Російській федерації: т. чорна, т. бальзамічна, т. канадська (P. canadensis Marsh.), т. лавролиста (P. laurifolia Ledeb.), т. духмяна (P. suaveolens Fisch.) [3].

Численні фітохімічні дослідження $[1,2,4-6]$ свідчать, що бруньки тополь містять значну кількість фенольних сполук: флавоноїди (піностробін, піноцембрин, пінобаксин, хризин, галангін, апігенін), фенолкарбонові кислоти ( $n$-кумарова, корична, кофейна, ферулова, хлорогенова), фенологлікозиди (саліцин, салікортин, популін, тремулоїцин); ефірну олію, смоли.

Поряд із бруньками, значний науковий і практичний інтерес як перспективна лікарська рослинна сировина представляє і листя тополь: по-перше, листя має близький до бруньок хімічний склад; по-друге, на відміну від бруньок, заготовляти цей вид сировини значно легше; по-третє, можливий об'єм заготівлі сировини значно більший.

Тополя лавролиста (Populus laurifolia Ledeb.) належить до секції Бальзамічні тополі (Tacamahaca). Морозостійка, світлолюбна, добре росте на прирічкових, вологих, піщаних грунтах. В Україні ії вирощують у лісовій культурі, використовують для озеленення і створення полезахисних насаджень.

Продовжуючи комплексне фармакогностичне вивчення сировини рослин роду Тополя, метою роботи було дослідження складу та вмісту сполук, що переганяються з водяною парою, листя тополі лавролистої, яку культивують в Україні.

\section{М а т е р і ли та ме тоди дослідження}

Листя для досліджень заготовляли у червні 2019 р. 3 дерев, що ростуть по берегах Муромського водосховища у с. Руські Тишки Харківського р-ну Харківської області (5009'30" с. ш. 36²9'10" в. д.). Визначення виду здійснювали за сприяння

(C) А. М. Рудник, 2021 
кандидата біологічних наук, доцента Гамулі Ю. Г., порівнюючи з гербарними зразками, які зберігаються на кафедрі ботаніки та екології Харківського національного університету ім. В. Н. Каразіна. Висушували повітряно-тіньовим способом упродовж 3 днів. Після збору сировину приводили у стандартний стан відповідно до загальних вимог належної практики культивування та збору лікарських рослин (GACP).

Компонентний склад сполук, що переганяються з водяною парою, досліджували на хроматографi Agilent Technologies 6890N (США) із мас-спектрометричним детектором 5973N за методикою, наведеною у [7]. Сполуки ідентифікували порівнянням одержаних мас-спектрів із даними бібліотеки мас-спектрів NIST05 i WILEY 2007 із використанням програм для ідентифікації AMDIS і NIST. Розрахунок вмісту компонентів виконували методом внутрішнього стандарту.

Статистичне оброблення результатів здійснювали відповідно до вимог ДФУ 2.0 5.3.N.1 «Статистичний аналіз результатів хімічного експерименту N» із використанням програми «SPSS Statistics 26.0». Використовували непараметричний критерій Манна-Вітні, у разі порівняння статистичних показників був прийнятий рівень значущості $p<0,05$.

Результати дослідження та обговорення

При хроматографічному аналізі (рисунок) сполуки, що переганяються з водяною парою, листя тополі лавролистої розділились на 58 компонентів, загальним вмістом 2 126,1 мг/кг, 46 я яких вдалось ідентифікувати. Склад та вміст ідентифікованих сполук наведено в таблиці. Вміст не ідентифікованих сполук становив 209,1 мг/кг. Серед ідентифікованих компонентів частка терпеноїдів становить 20 сполук загальним вмістом 1444 мг/кг, решта 26 - ароматичні сполуки (256,2 мг/кг) та сполуки різних груп (216,8 мг/кг).

Abundance

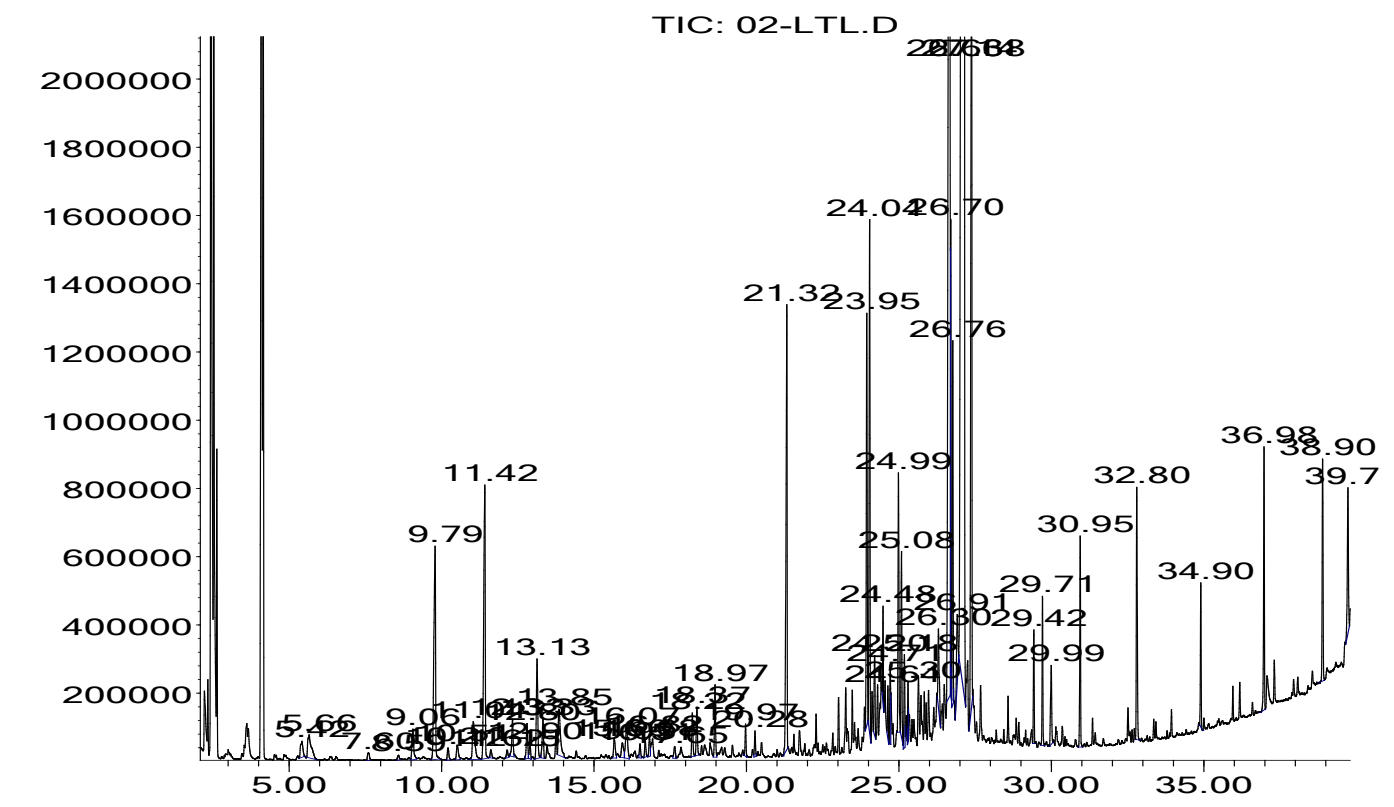

Time-->

Рис. Схема хроматограми сполук, що переганяються з водяною парою, листя Populus laurifolia Ledeb. 
Сполуки, що переганяються $з$ водяною парою, листя Populus laurifolia Ledeb. ( $n=3, p \leq 0,05)$

\begin{tabular}{|c|c|c|c|}
\hline $\begin{array}{l}\text { № } \\
\text { 3/II }\end{array}$ & $\begin{array}{c}\text { Час утримання, } \\
\text { Хв }\end{array}$ & Сполука & Вміст, мг/кг \\
\hline \multicolumn{4}{|c|}{ Ациклічні монотерпеноїди } \\
\hline 1 & 13,32 & Ліналоол & $7,2 \pm 0,06$ \\
\hline 2 & 12,32 & Транс-ліналоолоксид & $7,2 \pm 0,05$ \\
\hline 3 & 12,89 & Цис-ліналоолоксид & $2,9 \pm 0,07$ \\
\hline 4 & 15,92 & Епоксиліналоол & $4,4 \pm 0,05$ \\
\hline 5 & 17,64 & $\beta$-Циклоцитраль & $2,4 \pm 0,08$ \\
\hline \multicolumn{4}{|c|}{ Моноциклічні монотерпеноїди } \\
\hline 6 & 16,81 & $\alpha$-Терпінеол & $3,4 \pm 0,03$ \\
\hline 7 & 16,06 & Борнеол & $8,9 \pm 0,09$ \\
\hline \multicolumn{4}{|c|}{ Аииклічні сесквітерпеноїди } \\
\hline 8 & 29,42 & Гексагірофарнезилацетон & $11,8 \pm 0,10$ \\
\hline \multicolumn{4}{|c|}{ Моночиклічні сесквітерпеноїди } \\
\hline 9 & 27,38 & $\alpha$-Бісаболол & $125,9 \pm 2,15$ \\
\hline 10 & 23,94 & $a r$-Куркумен & $54,3 \pm 1,20$ \\
\hline \multicolumn{4}{|c|}{ Біщуиклічні сесквітерпеноїди } \\
\hline 11 & 27,13 & $\beta$-Евдесмол & $776,4 \pm 5,57$ \\
\hline 12 & 26,66 & $\gamma$-Евдесмол & $298,0 \pm 3,36$ \\
\hline 13 & 26,76 & Хінесол & $39,4 \pm 1,20$ \\
\hline 14 & 24,20 & $\alpha$-Аморфен & $10,6 \pm 0,09$ \\
\hline 15 & 24,47 & $\alpha$-Агарофуран & $9,1 \pm 0,08$ \\
\hline 16 & 24,63 & $\delta$-Кадінен & $5,8 \pm 0,07$ \\
\hline 17 & 24,71 & $\alpha$-Каламенен & $10,3 \pm 0,10$ \\
\hline 18 & 25,08 & $\alpha$-Калакорен & $21,6 \pm 0,11$ \\
\hline \multicolumn{4}{|c|}{ Трициклічні сесквітерпеноїди } \\
\hline 19 & 24,98 & $\alpha$-Копаєн-11-ол & $32,9 \pm 0,17$ \\
\hline 20 & 25,17 & Елемол & $11,5 \pm 0,13$ \\
\hline \multicolumn{4}{|c|}{ Ароматичні сполуки } \\
\hline 21 & 21,32 & Евгенол & $70,9 \pm 0,80$ \\
\hline 22 & 9,05 & Фенол & $7,5 \pm 0,05$ \\
\hline 23 & 11,61 & 2-Метилфенол & $1,6 \pm 0,02$ \\
\hline 24 & 12,80 & 2-Метоксифенол & $6,6 \pm 0,04$ \\
\hline 25 & 16,50 & 4-Метокси-2-вінілфенол & $2,5 \pm 0,03$ \\
\hline 26 & 20,27 & 2-Метокси-4-вінілфенол & $3,6 \pm 0,03$ \\
\hline 27 & 12,14 & Ацетофенон & $1,5 \pm 0,02$ \\
\hline 28 & 11,41 & Саліциловий альдегід & $57,0 \pm 0,70$ \\
\hline 29 & 29,99 & Бензилсаліцилат & $12,5 \pm 0,10$ \\
\hline 30 & 16,68 & Метилсаліцилат & $2,8 \pm 0,03$ \\
\hline 31 & 8,58 & Бензальдегід & $1,1 \pm 0,02$ \\
\hline 32 & 11,04 & Бензиловий спирт & $12,7 \pm 0,15$ \\
\hline 33 & 13,85 & $\beta$-Фенілетиловий спирт & $14,5 \pm 0,17$ \\
\hline 34 & 24,04 & $\beta$-Фенілетил-2-метилбутират & $61,4 \pm 0,80$ \\
\hline
\end{tabular}


Продовження таблиці

\begin{tabular}{|c|c|l|c|}
\hline $\begin{array}{c}\text { № } \\
\text { 3/п }\end{array}$ & $\begin{array}{c}\text { Час утримання, } \\
\mathbf{x в}\end{array}$ & \multicolumn{2}{|c|}{ Сполука } \\
\hline \multicolumn{3}{|c|}{ Інші сполуки } \\
\hline 35 & 32,80 & Фітол & $33,1 \pm 0,60$ \\
\hline 36 & 5,41 & Цис-3-гексен-1-ол & $5,2 \pm 0,03$ \\
\hline 37 & 5,65 & Транс-2-гексен-1-ол & $11,2 \pm 0,16$ \\
\hline 38 & 15,66 & 2,6-Нонадісн-1-ол & $4,3 \pm 0,02$ \\
\hline 39 & 9,78 & 1,2-Циклогександіон & $55,0 \pm 0,50$ \\
\hline 40 & 7,60 & 2-Циклогексен-1-он & $1,9 \pm 0,03$ \\
\hline 41 & 13,13 & 2,5-Октандіон & $19,5 \pm 0,23$ \\
\hline 42 & 10,21 & 2,4-Гептадиеналь & $2,5 \pm 0,01$ \\
\hline 43 & 18,97 & Транс-2-деценаль & $11,0 \pm 0,06$ \\
\hline 44 & 34,90 & Трикозан & $15,6 \pm 0,12$ \\
\hline 45 & 36,97 & Пентакозан & $31,3 \pm 0,17$ \\
\hline 46 & 38,89 & Гептакозан & $26,2 \pm 0,13$ \\
\hline
\end{tabular}

П р и м і тк а: $n=3, p \leq 0,05$.

Терпеноїдні сполуки листя тополі лавролистої переважно представлені сесквітерпеноїдами (13 сполук, загальним вмістом 1 407,6 мг/кг) та монотерпеноїдами (7 сполук - 36,4 мг/кг). Домінуючими є біциклічні сесквітерпеноїди - $\beta$ - та $\gamma$-евдесмоли (776,4 та 298,0 мг/кг відповідно) і моноциклічний сесквітерпеноїд $\alpha$-бісаболол $(125,9$ мг/кг), що є характерним для ефірної олії вегетативних і генеративних органів бальзамічних тополь [8-10]. Визначення вмісту ізомерів евдесмолу в подальшому може бути використано для ідентифікації лікарської рослинної сировини - листя тополі.

Ефірна олія листя тополі лавролистої характеризується високим вмістом кисневмісних сполук, лише 8 ідентифікованих сполук не містять кисень (загальний вміст 176,7 мг/кг). Кисневмісні сполуки представлені 21 спиртом (1 481,7 мг/кг), 5 альдегідами (74,0 мг/кг), 6 кетонами (89,7 мг/кг), 2 оксидами $(10,1$ мг/кг), 3 етерами (76,7 мг/кг). Щодо інших ідентифікованих сполук різних груп, то у найбільшій кількості в ефірній олії міститься кетон 1,2-циклогександіон - 55,0 мг/кг, 2,5-октандіон - 19,5мг/кг та насичені вуглеводні три- пента- та гептакозан - 73,1 мг/кг.

Серед 27 сполук нетерпенової природи - 18 похідних фенолу (256,2 мг/кг). У найбільшій кількості містяться евгенол - 70,9 мг/кг, етер $\beta$-фенілетил-2-метилбутират - 61,4 мг/кг та $\beta$-фенілетиловий спирт - 14,5 мг/кг, саліциловий альдегід 57,0 мг/кг, бензиловий спирт - 12,7 мг/кг та бензилсаліцилат - 12,5 мг/кг. Саліцилова i бензойна кислоти є основними агліконами фенологлікозидів рослин роду Populus (саліцин, популін, салікортин, тремулоидин), які зумовлюють протизапальну активність екстрактів із сировини. Похідні цих кислот є складовими компонентами ефірної олії бруньок, листя та кори бальзамічних тополь.

Одержані дані свідчать про багатий хімічний склад листя тополі лавролистої і $є$ підставою для подальшого поглибленого вивчення цієї сировини, для оцінки можливості використання її як лікарської. Листя тополі лавролистої, сухі і густі екстракти, одержані з нього, є перспективною сировиною для створення нових капсульованих і таблетованих лікарських засобів із вираженою протизапальною, антибактеріальною, аналгетичною і діуретичною активністю.

\section{В и с н о в к и}

1. Вперше методом хромато-мас-спектрометрії визначено вміст та склад сполук, що переганяються з водяною парою, листя Populus laurifolia Ledeb., яка культивується в Україні. 
2. Встановлено, що загальний вміст сполук, що переганяються з водяною парою, становив 2 126,1 мг/кг. Ідентифіковано 46 сполук. Домінуючими за вмістом виявились: $\beta$-евдесмол - 776,4 мг/кг, $\gamma$-евдесмол - 298 мг/кг, $\alpha$-бісаболол - 125,9 мг/кг, евгенол $-70,9$ мг/кг.

3. Одержані дані свідчать про перспективність створення фітопрепаратів на основі листя тополі лавролистої з вираженою протизапальною, антибактеріальною, аналгетичною і діуретичною активністю.

С п и с ок в и ко ри с т а ної літ ер ат у ри

1. Бородіна Н. В. Фармакогностичне дослідження рослин родини Вербові та створення на їх основі лікарських засобів: дис. ... д-ра фарм. наук: 15.00.02. - Харків, 2021. - 575 с.

2. Poblocka-Olech L., Migas P., Krauze-Baranowska M. TLC determination of some flavanones in the buds of different genus Populus species and hybrids // Acta Pharmaceutica. - 2018. - N 68 (2). - P. 199-210. https://doi.org/10.2478/acph-2018-0018

3. Куркин В. А., Куприянова Е. А. Сравнительное исследование флавоноидного состава листьев фармакопейных видов рода Populus // Химия растительного сырья. - 2020. - № 1. - С. 117-124. https:// doi.org/10.14258/jcprm.2020015818

4. Куприянова E. A. Сравнительное фармакогностическое исследование представителей рода тополь (Populus L.): дис. ... канд. фарм. наук: 14.04.02. - Самара, 2020. - 209 c.

5. Pobłocka-Olech L., Inkielewicz-Stepniak I., Krauze-Baranowska M. Antiinflammatory and antioxidative effects of the buds from different species of Populus in human gingival Pbroblast cells: role of bioflavanones // Phytomedicine. - 2019. - V. 56. - P. 1-9. https://doi.org/10.1016/j.phymed.2018.08.015

6. Kus P. M., Okinczyc P., Jakovljevic M., Jokic S., Jerkovic I. Development of supercritical CO2 extraction of bioactivephytochemicals from black poplar (Populus nigra L.) buds followed by GC-MS and UHPLC-DADQqTOF-MS // J. Pharmac. Biomed. Analysis. -2018.-V. 158. - P. 15-27.https://doi.org/10.1016/j.jpba.2018.05.041

7. Krechun A. V., Mykhailenko O. A., Kovalev V. N. Analysis of essential oils from several hybrid Iris varieties // Chem. Nat. Compd. - 2020. - N 56. - P. 361-363. https://doi.org/10.1007/s10600-020-03033-y

8. Рудник A. М. Дослідження сполук, що перегоняються з водяною парою, листя тополі волосистоплідної // Norwegian J. of development of the International Science. - 2019. - V. 1, N 37. - P. 40-43.

9. Altantsetseg Sh., Shatar S., Amarjargal A. et al. Chemical composition of the essential oil of Populus laurifolia Ledeb. from Mongolian Dzungarian Gobi / Матер. межд. науч.-практ. конф. «География, экология Алтая: состояние, охрана и устойчивое развитие», 27-28 октября 2017 г., Горно-Алтайск. - С. 61-64.

10. Stanciauskaite M., Marksa M., Liaudanskas M. et al. Extracts of Poplar Buds (Populus balsamifera L., Populus nigra L.) and Lithuanian Propolis: Comparison of Their Composition and Biological Activities // Plants. - 2021. - N 10 (5). - P. 828. https://doi.org/10.3390/plants10050828

\section{R e f e r e n s e s}

1. Borodina $N$. V. Farmakohnostychne doslidzhennia roslyn rodyny Verbovi ta stvorennia na yikh osnovi likarskykh zasobiv: dys. ... dokt. farm. nauk: 15.00.02. - Kharkiv, 2021. $-575 \mathrm{~s}$.

2. Poblocka-Olech L., Migas P., Krauze-Baranowska M. TLC determination of some flavanones in the buds of different genus Populus species and hybrids // Acta Pharmaceutica. - 2018. - N 68 (2). - P. 199-210. https://doi.org/10.2478/acph-2018-0018

3. Kurkin V. A., Kupriyanova E. A. Sravnitelnoe issledovanie flavonoidnogo sostava listev farmakopeynyih vidov roda Populus // Himiya rastitelnogo syirya. - 2020. - № 1. - S. 117-124. https://doi.org/10.14258/ jcprm.2020015818

4. Kupriyanova E. A. Sravnitelnoe farmakognosticheskoe issledovanie predstaviteley roda topol (Populus L.): dis. ... kand. farm. nauk: 14.04.02. - Samara, 2020. $-209 \mathrm{~s}$.

5. Poblocka-Olech L., Inkielewicz-Stepniak I., Krauze-Baranowska M. Antiinflammatory and antioxidative effects of the buds from different species of Populus in human gingival bbroblast cells: role of bioflavanones // Phytomedicine. - 2019. - V. 56. - P. 1-9. https://doi.org/10.1016/j.phymed.2018.08.015

6. Kus P. M., Okinczyc P., Jakovljevic M. et al. Development of supercritical $\mathrm{CO} 2$ extraction of bioactivephytochemicals from black poplar (Populus nigra L.) buds followed by GC-MS and UHPLC-DADQqTOF-MS // J. Pharmac. Biomed. Analysis. -2018.-V. 158. - P. 15-27.https://doi.org/10.1016/j.jpba.2018.05.041

7. Krechun A. V., Mykhailenko O. A., Kovalev V. N. Analysis of essential oils from several hybrid Iris varieties // Chem. Nat. Compd. - 2020. - N 56. - P. 361-363. https://doi.org/10.1007/s10600-020-03033-y

8. Rudnyk A. M. Doslidzhennia spoluk, shcho perehoniaiutsia $\mathrm{z}$ vodianoiu paroiu, lystia topoli volosystoplidnoi // Norwegian J. of development of the International Science. - 2019. - V. 1, N 37. - P. 40-43.

9. Altantsetseg Sh., Shatar S., Amarjargal A. et al. Chemical composition of the essential oil of Populus laurifolia Ledeb from Mongolian Dzungarian Gobi / Mater. mezhd. nauch.-prakt. konf. «Geografiya, ekologiya Altaya: sostoyanie, ohrana i ustoychivoe razvitie», 27-28 oktyabrya 2017 g., Gorno-Altaysk. - S. 61-64.

10. Stanciauskaite M., Marksa M., Liaudanskas M. et al. Extracts of Poplar Buds (Populus balsamifera L., Populus nigra L.) and Lithuanian Propolis: Comparison of Their Composition and Biological Activities // Plants. -2021 . - N 10 (5). - P. 828. https://doi.org/10.3390/plants10050828 
А. М. Рудник (https://orcid.org/0000-0003-2860-0967)

Запорізький державний медичний університет

ДОСЛІДЖЕННЯ СПОЛУК, ЩО ПЕРЕГАНЯЮТЬСЯ З ВОДЯНОЮ ПАРОЮ, ЛИСТЯ РОPULUS

LAURIFOLIA LEDEB.

Ключові слова: Populus laurifolia Ledeb., вербові, листя, сполуки, що переганяються з водяною парою, хромато-мас-спектрометрія

А Н О Т А Ц І Я

Одними з перспективних видів для внесення до Державної фармакопеї України є рослини роду тополя (Populus L.). На сьогодні накопичено великий досвід застосування екстрактів із бруньок, листя і кори різних видів тополь у народній й офіціальній медицині як ефективних протизапальних, жарознижувальних, аналгетичних, антибактеріальних засобів. За даними літератури, фармакопейною сировиною в деяких державах світу є тільки бруньки тополь. Як новий вид лікарської рослинної сировини, представляє інтерес і листя тополь, оскільки воно має близький до бруньок хімічний склад, заготовляти цей вид сировини значно легше і можливий об’єм заготівлі сировини значно більший.

Тополя лавролиста (Populus laurifolia Ledeb.) належить до секції Бальзамічні тополі (Tacamahaca). В Україні ії вирощують у лісовій культурі, використовують для озеленення і створення полезахисних насаджень.

Продовжуючи комплексне фармакогностичне вивчення сировини рослин роду Тополя, метою роботи було дослідження складу та вмісту сполук, що переганяються з водяною парою, листя тополі лавролистої, яку культивують в Україні.

Листя для досліджень заготовляли у червні 2019 року з дерев, що ростуть по берегах Муромського водосховища у с. Руські Тишки Харківського р-ну Харківської області (5009'30" с. ш. 36²9'10" в. д.). Компонентний склад сполук, що перегоняються з водяною парою, досліджували на хроматографі Agilent Technologies 6890N (США) із мас-спектрометричним детектором 5973N.

Встановлено, що загальний вміст сполук, що переганяються з водяною парою, становив 2126,1 мг/кг. Ідентифіковано 46 сполук. Серед ідентифікованих компонентів частка терпеноїдів становить 20 сполук загальним вмістом 1444 мг/кг, решта 26 сполук - ароматичні сполуки $(256,2$ мг/кг) та сполуки різних груп (216,8 мг/кг). Домінуючими за вмістом виявились: $\beta$-евдесмол - 776,4 мг/кг, $\gamma$-евдесмол 298 мг/кг, $\alpha$-бісаболол - 125,9 мг/кг, евгенол - 70,9 мг/кг.

Одержані дані свідчать про багатий хімічний склад листя тополі лавролистої і є підставою для подальшого поглибленого вивчення цієї сировини, для оцінки можливості використання іiї як лікарської.

А. М. Рудник (https://orcid.org/0000-0003-2860-0967)

Запорожский государственный медичинский университет

ИССЛЕДОВАНИЕ СОЕДИНЕНИЙ, ПЕРЕГОНЯЮЩИХСЯ С ВОДЯНЫМ ПАРОМ, ЛИСТЬЕВ

POPULUS LAURIFOLIA LEDEB.

Ключевые слова: Populus laurifolia Ledeb., вербовые, листья, эфирное масло, хромато-массспектрометрия

А Н Н О Т А Ц И Я

Одними из перспективных видов для внесения в Государственную фармакопею Украины являются растения рода тополь (Populus L.). Сегодня накоплен большой опыт применения экстрактов из почек, листьев и коры разных видов тополей в народной и официнальной медицине в качестве эффективных противовоспалительных, жаропонижающих, анальгетических, антибактериальных средств. По данным литературы, в некоторых странах мира фармакопейным сырьем являются только почки тополей.

Как новый, перспективный вид лекарственного растительного сырья представляют интерес именно листья тополей, поскольку они имеют близкий к почкам химический состав, заготавливать их значительно легче и возможный объем заготовки сырья значительно больше.

Тополь лавролистный (Populus laurifolia Ledeb.) отнесен к секции бальзамических тополей (Tacamahaca). В Украине его выращивают в лесной культуре, используют для озеленения и создания полезащитных насаждений.

Продолжая комплексное фармакогностическое изучение сырья растений рода Тополь, целью этой работы было изучение состава и содержания соединений, перегоняющихся с водяным паром, листьев тополя лавролистного, культивируемого в Украине.

Листья для исследований заготавливали в июне 2019 года с деревьев, растущих по берегам Муромского водохранилища в селе Русские Тишки Харьковского района Харьковской области $\left(50^{\circ} 09^{\prime} 30^{\prime \prime}\right.$ с. ш. $36^{\circ} 29^{\prime} 10^{\prime \prime}$ в. д.). Компонентный состав соединений, перегоняющихся с водяным паром, исследовали на хроматографе Agilent Technologies 6890N (США) с масс-спектрометрическим детектором 5973N.

Установлено, что общее содержание соединений, перегоняющихся с водяным паром, составило 2 126,1 мг/кг. Идентифицировано 46 соединений. Среди них доля терпеноидов составляет 20 соединений общим содержанием 1444 мг/кг, остальные 26 соединений - ароматические вещества $(256,2$ мг/кг) и соединения различных групп (216,8 мг/кг). Доминирующими по содержанию оказались: $\beta$-эвдесмол - 776,4 мг/кг, $\gamma$-эвдесмол - 298 мг/кг, $\alpha$-бисаболол - 125,9 мг/кг, эвгенол - 70,9 мг/кг.

Полученные данные свидетельствуют о богатом химическом составе листьев тополя лавролистного и являются основанием для углубленного изучения этого вида растительного сырья, для оценки возможности применения его как лекарственного. 
A. M. Rudnyk (https://orcid.org/0000-0003-2860-0967)

Zaporizhzhia State Medical University

THE STUDY OF COMPOUNDS DISTILLED WITH WATER VAPOR OF POPULUS LAURIFOLIA

LEDEB. LEAVES

Key words: Populus laurifolia Ledeb., willow family, leaves, compounds distilled with water vapor, gas chromatography-mass spectrometry

A B S T R A C T

Poplar plants (Populus L.) are one of the promising species for inclusion in the State Pharmacopoeia of Ukraine. To date, extensive experience has been accumulated in the use of extracts from buds, leaves and bark of various types of poplars in folk and official medicine as effective anti-inflammatory, antipyretic, analgetic, antibacterial agents. According to literature data only buds are pharmacopoeial raw materials in some countries of the world.

Poplar leaves are of interest as a new promising type of medicinal plant raw material, since they have a chemical composition close to the buds, moreover, they are much easier to harvest and the possible volume of raw materials procurement is much larger.

The laurel-leaf poplar (Populus laurifolia Ledeb.) is assigned to the section of balsamic poplars (Tacamahaca). It is grown in forest culture, used for landscaping and creation of field-protective plantations in Ukraine.

Continuing a comprehensive pharmacognostic study of raw materials of plants of the genus poplar, purpose of this work was to study composition and content of compounds distilled with water vapor of leaves of laurelleaf poplar cultivated in Ukraine.

Leaves for research were harvested in June 2019, from trees growing on the shores of the Murom reservoir in the village of Russkiye Tishki, Kharkiv region $\left(50^{\circ} 09^{\prime} 30^{\prime \prime} \mathrm{N} 36^{\circ} 29^{\prime} 10^{\prime \prime} \mathrm{E}\right)$. The composition of compounds distilled in water vapor was investigated on Agilent Technologies 6890N (USA) chromatograph with a 5973N mass spectrometric detector.

The total content of compounds distilled with water vapor was $2126.1 \mathrm{mg} / \mathrm{kg}$. 46 compounds were identified. Terpenoids were presented by 20 compounds with a total content $1444 \mathrm{mg} / \mathrm{kg}$, the remaining 26 compounds were aromatic substances $(256.2 \mathrm{mg} / \mathrm{kg})$ and compounds of various groups $(216.8 \mathrm{mg} / \mathrm{kg})$. The dominant compounds in content were $\beta$-eudesmol (776.4 mg/kg), $\gamma$-eudesmol $(298 \mathrm{mg} / \mathrm{kg}), \alpha$-bisabolol $(125.9 \mathrm{mg} / \mathrm{kg})$, eugenol $(70.9 \mathrm{mg} / \mathrm{kg})$.

The data obtained indicate the rich chemical composition of leaves of laurel-leaf poplar and are the basis for further in-depth study of this raw material for assessment the possibility of using it as a medicine.

\section{Електронна адреса для листування з автором: аптіги@теta.иа}

(Рудник А. М.) 